\title{
Scott William Sloan
}

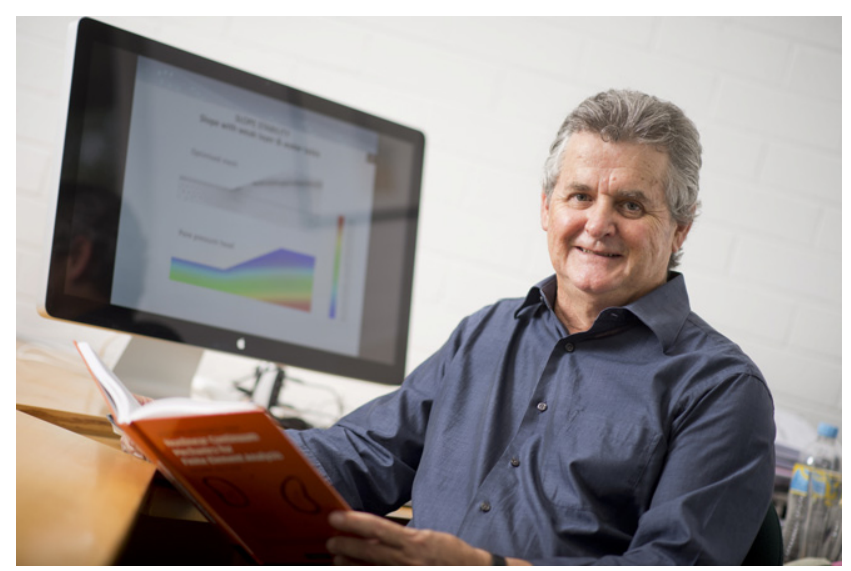

Professor Scott William Sloan BE, MEngSci(Monash), MPhil, PhD (Cantab), CPEng, FIEAust, MASCE, FAA, FTSE, FRS, FREng, AO, Laureate Professor of Civil Engineering, University of Newcastle, NSW, Australia (1954-2019)

Professor Scott William Sloan died suddenly on 23 April 2019, on board a charter fishing boat, while on a sports fishing family holiday along the coast of the Gulf of Carpentaria in the far north of Queensland. His unexpected demise, while pursuing one of his passions in one of his favourite locations on the planet, was a shock to all who knew him and has robbed the international geomechanics community of one of its most talented members.

Scott was born in the town of Mildura, Victoria, Australia, on 2 July 1954. He was the first child of Bill and Iris Sloan. Scott undertook his early schooling in Mildura, but around the time he was entering his teens, the family moved to Clarkefield, near Sunbury, north of Melbourne. He completed his school education at Sunbury High in 1971.

Scott entered Monash University in 1972, where he graduated with a first class honours degree in Civil Engineering in 1975. He taught himself to play blues guitar and briefly considered following a musical career. Subsequently, he obtained a Master of Engineering Science degree at Monash University in 1978.

In 1978 Scott moved to the University of Cambridge (UK) to study for a $\mathrm{PhD}$. He carried out research on incompressible solids as a member of the geotechnics research group. He was awarded a $\mathrm{PhD}$ degree in 1982 and his thesis was entitled 'Numerical analysis of incompressible and plastic solids using finite elements'.

After Cambridge, Scott moved to Oxford to undertake post-doctoral engineering research. He also spent some time at the University of Sydney working with one of his mentors, the late John Booker. In 1984 he moved to Newcastle, Australia to take up an appointment at the University of Newcastle as a lecturer in civil engineering. He remained at Newcastle for the rest of his professional career, rising rapidly through the ranks, becoming Senior Lecturer in 1989, Associate Professor in 1993 and Full Professor in 1998. Scott's presence at Newcastle led to the creation of a major research centre in geotechnical engineering, containing a large and highly successful team of established researchers, post-docs and students. Under his leadership, the centre drew international attention and built an enviable reputation in numerical modelling, and laboratory and field testing. The centre constitutes an enduring legacy to his determination and his vision. Since 2004, Scott Sloan was also a highly successful editor of the journal Computers and Geotechnics.

Scott's early research involved conventional displacement finite elements. He made several seminal contributions in this field, notably the development of higher order elements (i.e. the 15-noded triangle) to allow the accurate prediction of collapse loads; the formulation of semi-explicit solution schemes with adaptive error control for integrating elastoplastic stress-strain relationships and automatic incrementation; a novel algorithm for renumbering the degrees of freedoms, which results in significant savings in both computer memory and time, when solving the governing sparse stiffness matrix at the heart of a finite-element program; and a fast algorithm for constructing Delaunay triangulations, which is used to develop finite-element meshes consisting of triangular elements; to name but a few. These developments are incorporated in the software developed at Newcastle, but they are also in many bespoke finite-element codes developed at universities and research centres around the world and in commercial software packages.

Scott further pioneered, developed and wrote software to perform finite-element limit analyses. This method combines the limit theorems of classical plasticity, finite elements and large-scale optimisation. This method gives both upper and lower bounds to collapse loads directly, without the need to trace the complete load-displacement path, and has the invaluable advantage of an inbuilt error indicator. Both twoand three-dimensional problems can be solved and the method is gradually replacing the widely used method of limit equilibrium. The initial research was published in 1988 , but Scott and his colleagues at Newcastle continued to develop and improve the method and were still working on this at his demise. Before the limit theorems were combined with finite elements and optimisation, they were only suitable for simple cases amenable to analytical solutions; now they can be applied to complex problems of engineering significance. Scott's research in this field formed the subject matter of his 2011 Rankine Lecture.

Scott's research interests were not restricted to computational methods. In the past he conducted research into rock falls, unsaturated soils and stochastic analysis. Recently, in collaboration with his colleagues at Newcastle, he was involved in a major project on soft clays. This involved laboratory and field testing and the construction and instrumentation of trial embankments at the Ballina, NSW, test site. This resulted in a major prediction exercise and an international symposium. Most recently he was excited by a new ground-breaking research project involving a discovery that hemp seed products were effective in removing certain perfluorochemical substances (PFASs) from polluted sites. This discovery has major potential for the clean-up of many contaminated sites worldwide, particularly those contaminated by fire-fighting chemicals, including many airports.

Scott Sloan had a stellar academic career and built an enviable international reputation based on, in equal measure, 
his outstanding research performance and findings and his amiable personality. According to Google Scholar, he is one of the most highly cited individuals in geotechnical engineering. His research work has been recognised by the award of numerous prizes and honours. He was elected to four learned societies/academies, namely: the Australian Academy of Technological Sciences and Engineering in 2000; the Australian Academy of Science in 2007; as an International Fellow to the UK's Royal Academy of Engineering in 2015 and the Royal Society of London, also in 2015. For the latter his certificate of election reads

Professor Sloan is distinguished for the development of pioneering new methods which can be used to predict the ultimate limit states of geostructures such as tunnels, dams, highways and foundations. Being able to estimate the limit load accurately, or in layman's terms - how much load can it carry before it fails - is complicated by the fact that the behaviour of the natural geological materials we have to deal with is very complicated.

His nomination also included his 20 best papers as selected by Scott himself. The references for these papers are given below. Over his career he published over 350 papers.

As further recognition of his outstanding contributions, Scott was named as the Government of New South Wales Scientist of the Year in 2015. In January 2018 Scott was made an Officer of the Order of Australia (AO) for 'distinguished service to education, particularly in the field of Geotechnical engineering, as an academic and researcher, to professional associations, and as a mentor of young engineers'. The latter was a very important part of his work - helping others to pursue excellence.

Indeed, Scott's pursuit of excellence extended to all facets of his life. He would work and rework drafts of a technical paper or a research grant application until he got the words just right. He implored others to do the same. He had only the best fishing equipment. He insisted that his friends should do the same. A wise recommendation, as two of the authors of this obituary have experienced first hand.

Scott was a warm, friendly, intelligent, humorous, generous, focused person, who throughout his life developed many friendships, both at home and abroad. Any meeting he attended, large or small, scientific or otherwise, was enlivened by his witty conversation, his sense of humour and his wisdom. He will be sadly missed by his numerous friends and colleagues all round the world.

Scott is survived by his wife, Denise, and his three children, Erica, Oscar and Rory, of whom he was immensely proud.

John P. Carter, University of Newcastle, NSW, Australia Antonio Gens, Universitat Politecnica de Catalunya, Barcelona, Spain

David M. Potts, Imperial College London, London, UK

\section{SELECTED BIBLIOGRAPHY}

Krabbenhøft, K., Lyamin, A. V., Hjiaj, M. \& Sloan, S. W. (2005). A new discontinuous upper bound limit analysis formulation. Int. J. Numer. Methods Engng 63, No. 7, 1069-1088.

Krabbenhøft, K., Lyamin, A. V. \& Sloan, S. W. (2007). Formulation and solution of some plasticity problems as conic programs. Int. J. Solids Structs 44, No. 5, 1533-1549.

Lyamin, A. V. \& Sloan, S. W. (2002). Lower bound limit analysis using nonlinear programming. Int. J. Numer. Methods Engng 55, No. 5, 573-611.

Lyamin, A. V. \& Sloan, S. W. (2002). Upper bound limit analysis using linear finite elements and nonlinear programming. Int. J. Numer. Analyt. Methods Geomech. 26, No. 2, 181-216.

Merifield, R. S., Sloan, S. W. \& Yu, H. S. (1999). Rigorous solutions for the bearing capacity of two layered clay soils. Géotechnique 49, No. 4, 471-490, https://doi.org/10.1680/geot.1999.49.4.471.

Merifield, R. S., Sloan, S. W. \& Yu, H. S. (2001). Stability of plate anchors in undrained clay. Géotechnique 51, No. 2, 141-153, https://doi.org/10.1680/geot.2001.51.2.141.

Salgado, R., Lyamin, A. V., Sloan, S. W. \& Yu, H. S. (2004). Two- and three-dimensional bearing capacity of foundations in clay. Géotechnique 54, No. 5, 297-306, https://doi.org/10.1680/ geot.2004.54.5.297.

Sheng, D. C., Sloan, S. W. \& Gens, A. (2004). A constitutive model for unsaturated soils: thermomechanical and computational aspects. Comput. Mech. 33, No. 6, 453-465.

Sheng, D. C., Sloan, S. W. \& Yu, H. S. (2000). Aspects of the implementation of critical state models. Comput. Mech. 26, No. 2, 185-196.

Sloan, S. W. (1987). A fast algorithm for constructing Delaunay triangulations in the plane. Adv. Engng Software 9, No. 1, 34-55.

Sloan, S. W. (1987). Substepping schemes for the numerical integration of elastoplastic stress-strain relations. Int. J. Numer. Methods Engng 24, No. 5, 893-911.

Sloan, S. W. (1988). Lower bound limit analysis using finite elements and linear programming. Int. J. Numer. Analyt. Methods Geomech. 12, No. 1, 61-67.

Sloan, S. W. (1989). A FORTRAN program for profile and wavefront reduction. Int. J. Numer. Methods Engng 28, No. 11, 2651-2679.

Sloan, S. W. (2013). Geotechnical stability analysis. Géotechnique 63, No. 7, 531-572, https://doi.org/10.1680/geot.12.RL.001.

Sloan, S. W. \& Abbo, A. J. (1999). Biot consolidation analysis with automatic time stepping and error control. Part 1: theory and implementation. Int. J. Numer. Analyt. Methods Geomech. 23, No. 6, 467-492.

Sloan, S. W. \& Kleeman, P. W. (1995). Upper bound limit analysis using discontinuous velocity fields. Comput. Methods Appl. Mech. Engng 127, No. 1-4, 293-314.

Sloan, S. W. \& Randolph, M. F. (1982). Numerical prediction of collapse loads using finite element methods. Int. J. Numer. Analyt. Methods Geomech. 6, No. 1, 47-76.

Ukritchon, B., Whittle, A. J. \& Sloan, S. W. (1998). Undrained limit analyses for combined loading of strip footings on clay. J. Geotech. Geoenviron. Engng, ASCE 124, No. 3, 265-276.

Ukritchon, B., Whittle, A. J. \& Sloan, S. W. (2003). Undrained stability of braced excavations in clay. J. Geotech. Geoenviron. Engng, ASCE 129, No. 8, 738-755.

Zhao, J. D., Sloan, S. W., Lyamin, A. V. \& Krabbenhøft, K. (2008). Bounds for shakedown of cohesive-frictional soils under moving surface loads. Int. J. Solids Structs 45, No. 11-12, 3290-3312. 